\title{
Outcome of Teenage Pregnancy Associated with Medical Conditions
}

\author{
Nigar Sultana ${ }^{1}$,Syed Rezaul Huq ${ }^{2}$,Tabassum Parvin ${ }^{3}$, M Anwar Hussain ${ }^{4}$, Md Abedur Rahaman ${ }^{5}$
}

\begin{abstract}
:
Objective: This study was carried out to evaluate the Maternal and fetal outcome of teenage Pregnancy with different medical conditions during Pregnancy in the selected high risk hospital population of Bangladesh.

Methods: This was a cross sectional study. The study was done on 50 (fifty) teenage pregnant adolescent admitted in the Dhaka medical college Hospital and Bangabandhu sheikh Mujib Medical University Hospital during the study period July 2004 to June 2005. Samples were selected randomly from the admitted patients. Results: Seventy five percent of the mother had complication during delivery, of them $21.42 \%$ had PPH, $14.28 \%$ had inadequate lactation, $10.71 \%$ had post partum eclampsia, another $10.71 \%$ had wound dehiscence, $7.14 \%$ had post spinal headache. Eighty four percent of the babies were alive, of them Forty percent required resuscitation. Ten percent were dead and $6 \%$ were still born. Fourty eight percent of the new born had birth weight less than $2.5 \mathrm{~kg}, 32 \%$ had more than $2.5 \mathrm{~kg}$. APGAR score at one minute varied between $5-7$ in $75 \%$ of cases and was $8-9$ in $22.5 \%$. Only $2 \%$ has $<5$. APGAR score at five minutes varied between $8-9$ in $92.5 \%$ of cases. $40 \%$ of the babies developed jaundice, 30\% babies were birth asphyxiated, IUGR $8 \%$, prematurely $6 \%$, congenital anomalies $4 \%$.
\end{abstract}

Conclusion: Outcome of teenage pregnancy with medical conditions is poor.

\section{Introduction:}

Teenage Pregnancy is a pregnancy that occurs in an adolescent. An adolescent is a female who has reached puberty and is 19 years old or younger. Puberty is a stage of adolescence when a girl can sexually reproduce.

It is well known that pregnancy in adolescent has an increased risk of adverse reproductive outcome. Adolescents aged 15 years or younger had higher risk of maternal deaths, early neonatal death and anaemia compared with women aged 20 to 24 years ${ }^{2}$. When maternal anemia is diagnosed before midpregnancy, it

1.Assistant Professor.Department of Gynecology and obstetrics, Bangabandhu Sheikh Mujib Medical University, Dhaka, Bangladesh e-mail: syedhug65@hotmail.com

2.Junior Consultan,Dhaka Medical College Hospital, Dhaka. Bangladesh

3. Assistant Professor, Department of Gynecology and obstetrics,Bangabandhu Sheikh Mujib Medical University, Dhaka, Bangladesh

4.Professor and Chairman of Department of Gynecology and obstetrics, Bangabandhu Sheikh Mujib Medical University, Dhaka, Bangladesh

5. Lecturer, Department of Physiology Dhaka Medical College

\section{Corresponding author:}

Assistant Professor.Department of Gynecology and obstetrics, Bangabandhu Sheikh Mujib Medical University, Dhaka, Bangladesh e-mail: syedhug65@hotmail.com has been associated with an increased risk of preterm delivery ${ }^{3}$.

Hypertension, especially severe hypertension, spicially associated with an appreciable increase in maternal and perinatal morbidity but not perinatal mortality ${ }^{4}$.

Friedman and Neff in women with no hypertension or proteinuria. Ferrazzani et $\mathrm{al}^{5}$ reported a perinatal mortality rate of 129 per 1000 in 147 women with proteinuric preeclampsia, and Lin et $\mathrm{al}^{6}$ reported a rate of 127 per 1000 in 79 nulliparas with preeclampsia

It is a general clinical observation that, the number of pregnant women with pregestational type 2 diabetes has become more frequent in the recent years: however, little knowledge exists concerning the prevalence and outcome of these pregnancies ${ }^{7,8}$.

\section{Materials \& Methods}

This was a cross sectional study. The study was done on 50 teenage patients admitted in Dhaka Medical College Hospital and Bangabandhu Sheikh Mujib Medical University Hospital during the study period July 2004 to June 2005. Samples were selected randomly from the admitted patients. A datasheet/questionnaire was made. It was filled up with recording of all relevant parameters and these were then assessed and evaluated.

Careful history taking and thorough clinical examination was performed with the aim of detecting any clinical 
symptoms and signs suggestive of warning complication of pregnancy and delivery including perinatal complications. At entry into the study, a detailed history about socio demographic, past history, present history, record of antenatal check up and present complication was studied. On admission into labour ward, a questionnaire was filled up. Age of the patient was calculated in years and was recorded accordingly. Available standard care was provided to all and mode of delivery was recorded also. Perinatal mortality rate was calculated by foetal death after 28 weeks of gestation up to death within one week of delivery per 1000 live births. At birth, babies were examined for any congenital malformation. Babies were assessed by APGAR score at 1 and 5 minutes after birth, birth weight, admission to neonatal ward was recorded and final perinatal outcome was noted. Age distribution and birth weight of babies in grams was recorded and was analyzed. Results were analyzed by using statistical software programme SPSS version $^{12}$.

\section{Results:}

Maximum teenage pregnancy occurred in the age distribution between 17-18 years. Majority of teenage patients were house wives (78\%). Others are garments worker $12 \%$, day labour $6 \%$, maid $2 \%$, service holder $2 \%$. Majority of the mothers had primary education (60\%), followed by can sign only $18 \%$, Illiterate $16 \%$, secondary 6\%. There was little tendency of contraceptive use among teenage mothers. 64\% had never used it, $12 \%$ had irregular use, $14 \%$ mothers had contraception used by themselves and 10\% patients' husband used it. Socio Economic condition of teenage patients was poor. Most of the patients were low income group of Tk.3000 (58\%) followed by 36\% between Tk. 3000-5000 and only 6\% were under the income group of $>$ Tk.5000. Most of the patient had either irregular or infrequent or no antenatal checkup. Only 24\% had regular antenatal checkup.

All the teenage mothers had anemia either in mild form or in moderate form.

Among the teenage mothers in this study, nobody had jaundice except one which is unrelated to pregnancy. Thirty percent of the patients had no edema. Others had some sorts of edema either in mild or moderate form. But 4\% had developed severe edema. Tendency of high blood pressure was less in teenage mothers, seventy four percent of the mothers were normotensive. Twelve percent developed moderate hypertension and another Twelve percent developed severe hypertension also. no urine albumin was noted in $76 \%$ of the patients. $2 \%$ develops severe albuminuria, 14\% develops moderate albuminuria and $8 \%$ mild albuminuria. Thirty four percent of the patients had oligohydramnios, 3\% had polyhydramnios others had normal average amount of liquor. During delivery 50\% patient had normal duration, $34 \%$ showed prolonged first stage, $14 \%$ cases had prolonged second stage. Seventy five percent of the mother had complication during delivery of them $21.42 \%$ had $\mathrm{PPH}, 14.28 \%$ had inadequate lactation, $10.71 \%$ had post partum eclampsia, another $10.71 \%$ had wound dehiscence, $7.14 \%$ had post spinal headache. Eighty four percent of the babies were alive, of them $40 \%$ required resuscitation. $10 \%$ were dead and $6 \%$ were still born. $48 \%$ of the new born had birth weight less than $2.5 \mathrm{~kg}, 32 \%$ had more than $2.5 \mathrm{~kg}$. APGAR score at one minute varied between $5-7$ in $75 \%$ of cases and was $8-9$ in $22.5 \%$. Only $2 \%$ has $<5$. APGAR Score at five minutes varied between 8-9 in $92.5 \%$ of cases, highest mortality of babies were due to prolonged obstructed labour (37\%) followed by antepartum eclampsia (24\%), birth asphyxia (13\%). Fourty percent of the babies developed jaundice, $30 \%$ babies were asphyxiated, IUGR $8 \%$, prematurely $6 \%$, congenital anomalies 4\%.

\section{Discussions:}

The health and life of adolescent girls below the age of 19 are put at risk by pregnancy and childbirth, especially where living conditions are poor and health care inadequate. The younger the adolescent, greater the risk.

Regarding clinical parameter of the patient the incidence of anemia was much higher. All the teenage mothers were anemic. Either in mild form or in moderate form almost similar to study by Anita Pal et al.9 It was mostly nutritional anemia. In this series $70 \%$ patients had some sorts of edema in the form of either mild or moderate or severe. Twenty eight percent of the patients developed pregnancy induced hypertension, 2\% developed severe albuminurea, 14\% developed moderate albuminurea, and $8 \%$ had mild albuminurea.

Regarding the perinatal outcome, $84 \%$ of the babies were alive. Of them $40 \%$ required resuscitation, $10 \%$ were dead and $6 \%$ were still birth. The causes of mortality found in the study are due to antepartum eclampsia $25 \%$, obstructed labour $37.5 \%$, premature rupture of membrane $12.5 \%$, birth asphyxia $12.5 \%$. This study also coincides with a study of India1. Regarding morbidity of the baby $40 \%$ of the babies developed jaundice, $30 \%$ of the babies were birth asphyxiated, IUGR $8 \%$, prematurity $6 \%$, congenital anomalies $4 \%$.

The relationship between anemia or iron deficiency anemia and increased risk of preterm delivery $(<37 \mathrm{wk}$ 
gestation) has been found by several studies ${ }^{1,13}$. Hypertension, especially severe hypertension, was associated with an appreciable increase in important maternal and perinatal morbidity but not perinatal mortality ${ }^{13}$.

Friedman and Neff in women with no hypertension or proteinuria. Ferrazzani et al. $^{5}$ reported a perinatal mortality rate of 129 per 1000 in 147 women with proteinuric preeclampsia, and Lin et al reported a rate of 127 per 1000 in 79 nulliparas with preeclampsia.

A study from Birmingham, U.K., showed a similar perinatal mortality but a higher frequency of congenital malformations, preterm delivery, large-forgestational-age infants, and fetal loss before 24 weeks' gestation in 57 pregnancies in women with type 2 diabetes compared with pregnancies in women with type 1 diabetes In 182 pregnancies in women with type 2 diabetes compared with the general population, there was a 2.5-fold greater risk of perinatal mortality and an 11-fold greater risk of a congenital malformation is. A study from New Zealand reported a threefold increased perinatal mortality rate in pregnancies related to type 2 diabetes compared with pregnancies related to type 1 diabetes. In addition, the study indicated that the outcome was poorer if type 2 diabetes was diagnosed during pregnancy compared with before pregnancy ${ }^{17}$.

Table I: Perinatal Outcome

\begin{tabular}{ll|l}
\hline $\begin{array}{l}\text { Perinatal } \\
\text { Outcome }\end{array}$ & Frequency \\
\hline \multirow{2}{*}{ Valid } & Alive with resuscitation & 22 \\
& Alive without & 205 \\
& resusc!tation Dead Still & 3 \\
birth Total & 50 \\
\hline
\end{tabular}

Table II: Weight of the baby

\begin{tabular}{|c|c|c|c|c|}
\hline \multicolumn{2}{|c|}{ I Morbidity of the baby } & \multirow{2}{*}{$\begin{array}{l}\text { Frequency } \\
\mid 3\end{array}$} & \multirow{2}{*}{\begin{tabular}{|l} 
Percent \\
6.0
\end{tabular}} & \multirow{2}{*}{\begin{tabular}{|l} 
Valid \\
Percent
\end{tabular}} \\
\hline \multirow{7}{*}{ Valid } & Prematurity & & & \\
\hline & \begin{tabular}{|l} 
Birth \\
Asphyxia
\end{tabular} & 9 & 18.0 & 30.0 \\
\hline & IUGR & 4 & 8.0 & 13.3 \\
\hline & Jaundice & 12 & 24.0 & 40.0 \\
\hline & Congenital & 2 & 4.0 & 6.7 \\
\hline & Anomalies & & & \\
\hline & Total & 30 & 60.0 & 100.0 \\
\hline \multirow[t]{2}{*}{ Missing } & System & 20 & 40.0 & \\
\hline & Total & 50 & 100.0 & \\
\hline
\end{tabular}

Table III: APGAR score of the baby at one minute

\begin{tabular}{|c|c|c|c|}
\hline \multicolumn{2}{|c|}{ APGAR score } & |Frequency & Percent \\
\hline Valid & \begin{tabular}{|l|}
$6-7$ \\
$8-9$ \\
Total \\
\end{tabular} & \begin{tabular}{|l|}
3 \\
37 \\
40
\end{tabular} & \begin{tabular}{|l|}
6.0 \\
74.0 \\
80.0
\end{tabular} \\
\hline Missing & $\begin{array}{l}\text { System } \\
\text { Total } \\
\end{array}$ & $\begin{array}{l}10 \\
50\end{array}$ & \begin{tabular}{|l|}
20.0 \\
100.0 \\
\end{tabular} \\
\hline
\end{tabular}

Table IV: APGAR score of the baby at five minute

\begin{tabular}{|l|l|l|l|l}
\hline \multicolumn{2}{|l|}{ APGAR score } & Frequency & Percent & $\begin{array}{l}\text { Valid } \\
\text { Percent }\end{array}$ \\
\hline \multirow{4}{*}{ Valid } & $<5$ & 1 & 2.0 & 2.5 \\
& $5-7$ & 30 & 60.0 & 75.0 \\
& $8-9$ & 9 & 18.0 & 22.5 \\
& Total & 40 & 80.0 & 100.0 \\
\hline \multirow{2}{*}{ Missing } & System & 10 & 20.0 & \\
& Total & 50 & 100.0 & \\
\hline
\end{tabular}

Table V: Morbidity of the baby

\begin{tabular}{|l|l|l|l|l|}
\hline \multicolumn{2}{|l|}{ Weight of the baby. } & Frequency & Percent & $\begin{array}{l}\text { Valid } \\
\text { Percent }\end{array}$ \\
\hline Valid & More than 2.5 & 16 & 32.0 & 40.0 \\
& Less than 2.5 & 24 & 48.0 & 60.0 \\
& Total & 40 & 80.0 & 100.0 \\
\hline Missing & System Total & 10 & 20.0 & \\
& & 50 & 100.0 & \\
\hline
\end{tabular}

\section{Bibliography}

1. Martin E. Teenage Pregnancy. Diseases and Conditions Encyclopaedia discovery health channel, real life, medicine, miracle / 1996.

2. Conde-Agudelo A, Belizan JM. Lammers C. Maternal-Perinatal morbidity and mortality associated with adolescent pregnancy in Latin America American J Obstet Gynecol 2005 Feb: 192(2): 342-9

3. Scholl T. 0. Reilly T. Anemia, iron and pregnancy outcome Journa of Nutrition 2000:130:4435-4475.

4. Hauth JC. Ewell MG. Levme RJ. Esterlitz JR. Sibai B Curet LB Catalano PM. Morris CD. .Pregnancy outcomes in healthy nulliparas who developed hypertension. Calcium for Preeclampsia Prevention Study Group. Obstet Gynecol 2000 Jan:95(1):24-8

5 Ferrazzani, Caruso A. De Carolis S. Martmo IV. Mancuso S Proteinuria and outcome of 444 pregnancies complicated by hypertension Am J Obstet Gynecol 1990:162:366-71.

6. Lin CC. Lmdheimer MD, River P. Moawad AH Fetal outcome in hypertensive disorders of pregnancy Am J Obstet Gynecol 1982: 142 255-60

7. Mokdad AH. Ford ES, Bowman BA, Nelson DE. Engelgau MM. V.mcor F. Marks JS: Diabetes trends in the U.S.: 1990-1998. Diabetes Care 200023 1278- 1283,

8. Feig DS Palda VA: Type 2 diabetes in pregnancy a growing concern. Lancet 2002: 359:1690-1692.

9. Anita P, Gupta K. ........dhawa Indian med assoc. Version No 5. Adolescent Pregnancy A iigh risk group, J May 1997: 128-29

10. Klebanoff M. A,. Shiono P. H. Selby J, V.. Trachtenberg A I., Graubarrl B preterm birth. Am, J, Obstet, Gyneco1. Anemia and spontaneous 1991:164:59-63

11. Lu Z. M., Goldenberg R. L.. Cliver S. P., Cutter G,. Blankson M The relationship between maternal hematocnt and pregnancy outcome. 
Obstet Gynecol. 1991:77:190-193

12. Scholl T. 0.. Hediger M. L. Anemia and iron deficiency anemia compilation of data on pregnancy outcome Am, J, On. Nutr 1994:59 492S-501S

13. Zhou L M.. Yang W. W.. Hua J. Z.. Deng C Q Tao X. Stolzfus R J Relation of hemoglobin measured at different times in pregnancy to preterm birth and low birth weight in Shanghai. China. Am J Epidemic 1998:148:998-1006

14. Brydon P. Smith T. Proffitt M. Gee H, Holder R Dunne F Pregnancy outcome in women with type 2 diabetes mellitus needs to be addressed fnt J Clin Pract2000: 54:418-419.

15. Dunne FP. Brydon PA. Proffitt M, Smith T, Gee H, Holder RL
Fetal ana maternal outcomes in Indo-Asian compared to Caucasian women with diabetes in pregnancy Q J Med 2000: 93:813-818

16. Dunne F. Brydon P, Smith K. Gee H: Pregnancy in women with type 2 diabetes: 12 years outcome data 1990-2002 Diabet Med 2003: 20:734-738

17. Cundy T, Gamble G. Townend K, Henley PG, Macpherson P Roberts AB Perinatal mortality in type 2 diabetes mellitus, Diabet Med 2000,17:33-39 